\title{
Sand composition in an Iberian passive-margin fluvial course: the Tajo River
}

\author{
Emilia Le Pera ${ }^{\mathrm{a}, *}$, José Arribas ${ }^{\mathrm{b}}$ \\ ${ }^{\mathrm{a} C}$ Consiglio Nazionale delle Ricerche-Istituto di Ricerca per la Protezione Idrogeologica, Sezione di Cosenza, Via Cavour, 4-6, \\ 87030 Roges di Rende (CS), Italy \\ ${ }^{\mathrm{b}}$ Departamento de Petrología y Geoquímica, Facultad de Ciencias Geológicas, Universidad Complutense de Madrid, \\ C/Josè Antonio Novais s/n, 28040 Madrid, Spain
}

\begin{abstract}
The Tajo River, the 10th largest river in Europe, drains part of the western passive margin of Europe that includes multiple tectonic elements of the Iberian plate. Modern fluvial sand composition in the Tajo River drainage basin reflects the nature of the source region, which lies in the central part of the Iberian Peninsula. Four fluvial petrographic provinces (A, B, C and D) can be established in the Tajo drainage basin, corresponding well with the four principal structural units drained: (1) the Iberian Range; (2) the Hesperian massif; (3) The Tertiary Tajo basin; and (4) the Neogene Santarem-Lisboa basin.

Province $A$ corresponds to the Tajo River head and is characterized by quartzolithic sedimenticlastic sands $\left(\mathrm{Qm}_{67} \mathrm{~F}_{4} \mathrm{Lt}_{29}\right.$ and $\mathrm{Rs}_{79} \mathrm{Rg}_{3} \mathrm{Rm}_{18}$ ). These sands have been derived from diverse Mesozoic siliciclastics and carbonates of the Iberian Range. Province $B$ appears in the upper reaches of the Tajo River course and is quartzofeldspathic $\left(\mathrm{Qm}_{57} \mathrm{~F}_{34} \mathrm{Lt}_{9}\right)$ with diverse rock fragments $\left(\mathrm{Rs}_{34} \mathrm{Rg}_{23} \mathrm{Rm}_{43}\right)$. Sources are Hercynian granitoids and metasediments and Neogene clastics and minor carbonates of the Tertiary Tajo basin. Province $C$ extends along the middle course of the Tajo River with quartzofeldspathic metamorphiclastic sand modes $\left(\mathrm{Qm}_{60} \mathrm{~F}_{33} \mathrm{Lt}_{7} ; \mathrm{Rs}_{4} \mathrm{Rg}_{21} \mathrm{Rm}_{75}\right)$. The sources are metamorphic rocks intruded by plutonites of the Hesperian Massif. Province $D$ is quartzofeldspathic $\left(\mathrm{Qm}_{55} \mathrm{~F}_{39} \mathrm{Lt}_{6}\right)$ with a dominance of phaneritic rock fragments $\left(\mathrm{Rs}_{5} \mathrm{Rg}_{33} \mathrm{Rm}_{62}\right)$ and corresponds to the lower reaches of the Tajo River, where siliciclastic deposits of the Neogene Santarem-Lisboa basin are the main sources. Sands plot on provenance-discrimination diagram (QmFLt) within the recycled-orogen field (Tajo River head) and continentalblock fields (upper, middle and lower course). In addition, we have proven the usefulness of the $R s R g R m$ diagram to discriminate the defined fluvial provinces, originating from heterogeneous parent-rock textures and mineralogy.

Climate does not exert any strong influence on the petrogenesis of the Tajo River drainage basin sand, and erosion in the source areas may be described in terms of weathering-limited denudation regime. By contrast, mixing with tributary supplies is the main process that modifies composition in the Tajo River sand. The establishment of fluvial provinces related to the main bedrock structural units reflects the great relevance of tributaries from each province in the generation of the Tajo River sand and the low significance of inherited sandy load from previous provinces.
\end{abstract}

\footnotetext{
* Corresponding author. Tel.: +39 984 835528; fax: +39 984835319.

E-mail addresses: emilia.lepera@irpi.cnr.it (E. Le Pera), arribas@geo.ucm.es (J. Arribas).
} 
The abundance of granitoid rock fragments (RsRgR\%Rg) in fluvial sand of both tributaries and main channel of the Tajo River drainage basin faithfully represents the relative abundance of granodiorite+monzogranite bedrock exposure in each subbasin. Metasedimentary and metamorphic bedrock outcrop area is overrepresented by metamorphic rock fragments (RsRgRm\%Rm) in both sand from thibutaries and from the Tajo main nunk river. This is manifested by differences of $1823 \%$ between means of metasedimentary outcrop area and the RsRgRm\%Rm mean in the sand from Provinces $\mathbf{B}$ and $\mathbf{C}+\mathbf{D}$, respectively. Sedimentary (mainly carbonate) outcrop area is underrepresented or not represented by sedimentary rock raments (RsRgRm\%Rs) in sand of the Tajo River. This underrepresentation causes a difference between means of sedimentary outcrop area and the RsRgRm\%Rs mean of $21 \%, 17.1 \%$ and $10.7 \%$ in sands from Province A, B and $\mathbf{C}+\mathbf{D}$, respectively. This fact confmns the rapid loss of these rains during ansport because of their labile nature.

- 2004 Elsevier B.V. All rights reserved.

Keywords: Sand; Petrofacies; Tajo River; Provenance; Fluvial basin

\section{Introduction}

Variøus factors combine to produce clastic assemblages found in modern and ancient sediments (Suttner, 1974). These factors include søurce-røck compøsition, tectonics, climate and relief, which together are being referred to as provenance (Dickinsøn, 1970; Basu, 1985). Modern fluvial and marine sands are especially suited for provenance studies, through framework composition (e.g., Dickinson and Valloni, 1980; Grantham and Velbel, 1988; Ibbeken and Schleyer, 1991; Jøhnssøn et al., 1991; Ingersøll et al., 1993; Critelli et al., 1997; Le Pera et al., 2001), accessøry minerals (Mange-Rajetzky, 1981; Morton and Smale, 1991) or both (Arribas et al., 2000; Garzanti et al., 2000), because of the absence of major post-depositiønal processes and presence of the physiographic and climatic correlation between source area and sedimentary basin (Valloni, 1985).

Understanding actualistic petrofacies, based on sand petrology of large river systems, is important for questions of global significance such as relating sand composition to relief, source røck, climate (Potter, 1978a,b; Jølmsson et al., 1988; DeCelles and Hertel, 1989; Blasi and Manassere, 1990) and plate tectonics (Dickinson and Suczek, 1979).

The Tajø River, the 10th largest river in Eurøpe, drains part of the western passive margin of Eurøpe that includes multiple tectonic elements of the Iberian plate (Fig. 1). The geløgic, geomorphølogic and climatic variabilities of the drainage basin provide an actualistic setting in which to study the relationships between sand composition and possible major factors -perating within the sedimentary system on a continental scale.

Small-scale studies on sand composition have been carrie $\bullet$ ut in tributaries of the Taj River (i.e., Tortosa et al., 1989; Palomares and Arribas, 1993; Arribas et al., 2000; Arribas and Tortosa, 2003). These studies have stressed the relevance of factors influencing sand compesition that operate during the first stage of sand generation (i.e., lithøløgy, sløpe and mixing processes).

The present study, focused on a larger scale, has importance to a general understanding of the quantification of how relief, climate and søurce rock affect the petrogenesis of siliciclastic sand, produced on a continental bløck. This knøwledge is a prerequisite to assessments of provenance based on clastic composition in the gelogical record. In addition, interpretation of ancient sandstones from passive continental margins can be improved by analogy with this actualistic provenance study.

\section{Geological setting}

The Tajø River has an asymmetric drainage basin (Elorza Gutierrez, 1994) located in the central part of the Iberian Peninsula (Fig. 1). The basin is nearly $660 \mathrm{~km}$ long and up to $140 \mathrm{~km}$ wide, being one of the big European Atlantic rivers. The Taj• River (1007 km long) flows westward, wandering across several structural units of the Iberian plate and debauching on the Iberian western passive margin (Fig. 1). In addition, a well-developed abyssal plain 

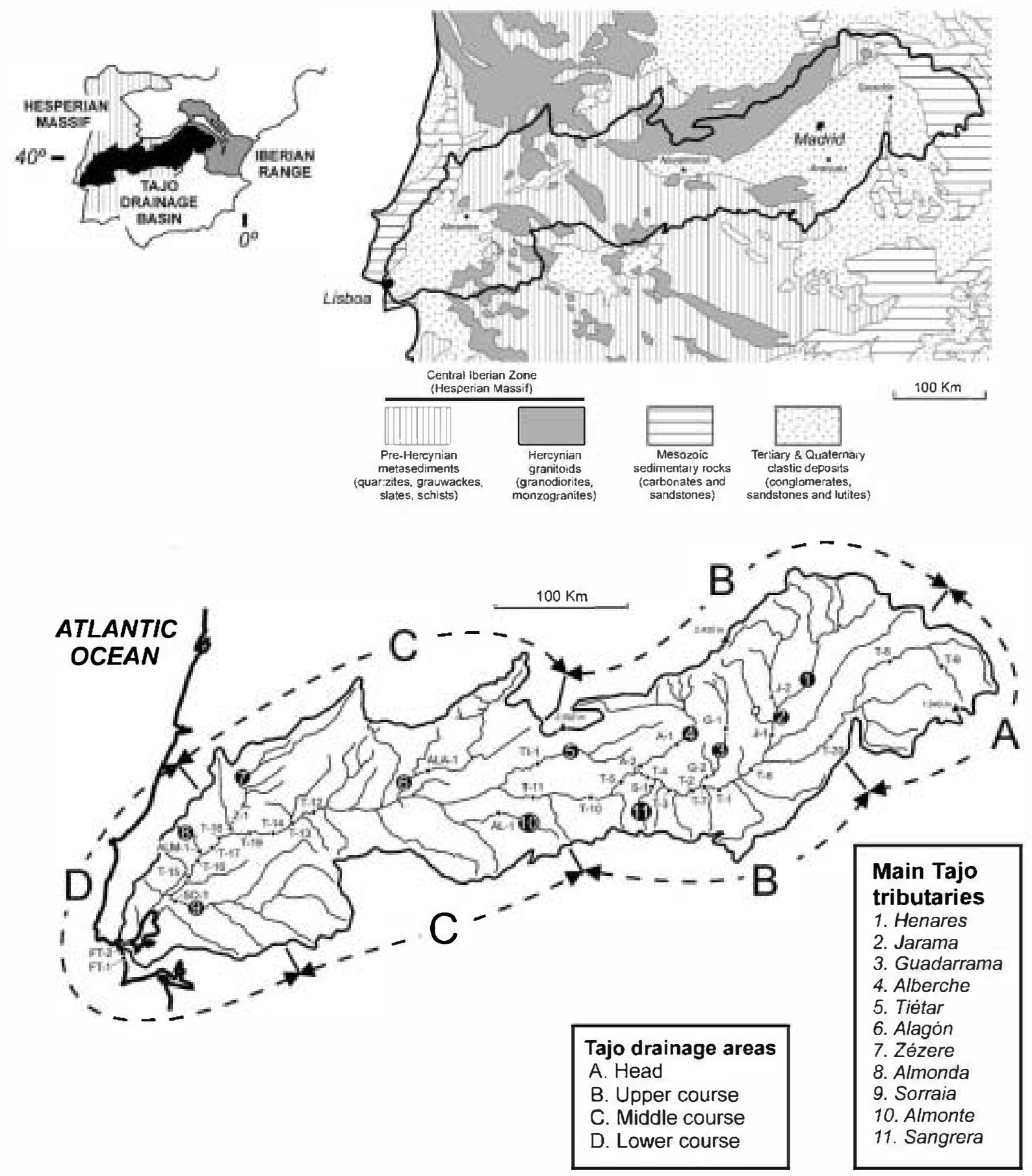

Fig. 1. Map showing generalised bedrock geology and fluvial drainage network of the Tajo River basin. Numbered dots indicate the location of samples. 
receives the final detritus yielded by the Taje drainage system. The principal river valley mainly incises Neøgene tabular deposits and some preHercynian metamorphic and crystalline terrane

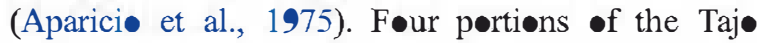
drainage basin with distinctive morpholegical and hydroløgical characteristics can be distinguished based on structural units: (1) the Iberian Range (at the head); (2) the Tertiary Tajø basin (upper course); (3) the Hesperian Massif (middle course); and (4) the Neøene Santarem-Lisbøa basin (løwer course) (A, $\mathrm{B}, \mathrm{C}$ and $\mathrm{D}$ zones in Fig. 1, respectively).

The Taj॰ river head (from its søurce tø Sacedón) is located in the Iberian Range, a NW-SE-trending Alpine chain consisting of Mesøzıic sedimentary strata (Triassic feldspathic sandstones, Jurassic and Cretace us marine carbønates and subarkesic sandstones). Streams and river courses are narrow, cutting the sedimentary bedrock without a welldeveløped alluvial plain (Arribas and Tortosa, 2003).

The Tertiary Taj basin, in the upper course, contains Neøene continental-clastic, carbonate and evapørite tabular formations. Neøgene clastics derive from the Alpine uplifted surrounding areas (Iberian Range at the east, the Central System at the north and the Tølede Møuntains at the søuth). In this track (frøm Sacedón t• Navalmøral), the Taj• River and its main tributaries develop wide alluvial plains with several Quaternary terraces and meander bars. In this segment, the northwest watershed of the drainage area is situated in the Central System, a mountainous range that consists of a large exposure of granitoids that intrude pre-Hercynian metamorphic basement.

The middle course (from Navalmoral to Abrantes) cuts løw-grade metamørphic røcks (Precambrian graywacke and slates, Cambrian slates and quartzites and asseciated intruding granitoids) from the Central Iberian Zøne in the Hesperian Massif. The Taj• River is deeply incise in this area, showing little development of alluvial depesits.

The løwer course $\bullet$ the Tajø River (frøm Abrantes to Lisbøa) is developed on the Santarem-Lisb Neøgene basin. Again, the tabular arrangement of the Tertiary detrital deposits favours the wandering course of the Tajø River, with a wide alluvial plain with meander bars and a well-developed system of Quaternary terraces. Estuarine deposits are als• present near the river mouth. Head streams of tributaries at the north and søuth alsø drain Jurassic carbønate and metamorphic terranes from Hesperian

Table 1

Physiographic and climatic characteristics of the Tajo River drainage basin

\begin{tabular}{|c|c|c|c|c|c|}
\hline \multicolumn{6}{|l|}{ Topography } \\
\hline Zone A & 1455 & 1417 & $12 \cdot 4$ & 10200 & $34 \bullet 4$ \\
\hline Zone B & 2000 & 1110 & 443 & 89360 & $34 \bullet 4$ \\
\hline Zone D & 569 & 405 & 56 & 23400 & 7234 \\
\hline \multicolumn{6}{|l|}{ Climate } \\
\hline & $\begin{array}{l}\text { Annual average } \\
\text { temperature }\left({ }^{\circ} \mathrm{C}\right)\end{array}$ & $\begin{array}{l}\text { Annual average } \\
\text { rainf all }(\mathrm{mm})\end{array}$ & Climate & & Leaching factor* \\
\hline Zone D & 16 & $750-1200$ & warm to humid temperate & & $22.2-67.2$ \\
\hline
\end{tabular}

* Leaching factor=mean annual precipitation $(\mathrm{cm})$ minus $3.3 \times$ mean annual precipitation $\left({ }^{\bullet} \mathrm{C}\right)$ (Crowther, 1930).

** $\mathrm{nth}=$ northern area; sth=southern area. 
Massif, respectively, cropping out at the edges of the Neøgene basin (Fig. 1).

The main topegraphic data that characterize the Tajø drainage basin are summarized in Table 1 . The elevation of the Taj River drainage basin varies from sea level to more than $2000 \mathrm{~m}$. The higher altitudes correspond to watershed in the Central System (Mount Almanzor, 2592 m; Møunt Peñalara, 2430 $\mathrm{m}$ ) and in the Iberian Range (Mount San Felipe, 1840 $\mathrm{m})$. Sløpes vary throughøut the basin. Thus, at the head (lberian Range), mean slope ranges from $20 \%$ to 30\% (Arribas and Tortosa, 2003). In the upper course, slopes at head streams of tributaries in the Central System are more gentle, from $10 \%$ to $30 \%$ (Palomares and Arribas, 1993; Arribas et al., 2000). Slope values drop drastically where the Tajø River and its tributaries cut int the Tertiary basin deposits (Tertiary Taj basin in the upper course and Tertiary SantaremLisbøa basin in the lower course). In the middle course, streams flowing across the metamorphic bedrøck of the Hesperian Massif show more gentle slopes than in the Central System.

The climates at the head, upper and middle courses can be considered as continental Mediterranean, while in the lower course, the influence of the Atlantic Ocean reduces the thermal amplitude and increases precipitation (Atlas Nacional de España, 1993) (Table 1). High values (750-1200 mm) of mean annual precipitation $\bullet$ ccur at the highest altitudes of mountainous areas (at the head and at the Central System) and in the lower part of the basin. At the lowlands of the inner the basin, mean annual precipitation decreases to less than $500 \mathrm{~mm}$. In addition, mean annual temperature in the interior areas differs from high to lowlands (frøm 7.5 to 12.5 ${ }^{\circ} \mathrm{C}$, respectively), but increasing to $16^{\circ} \mathrm{C}$ aløng the Atlantic coast.

According to these climatic parameters, and following Wilsøn's (1969) criteria, weathering varies from "moderate chemical weathering with frost action" in the highest zones of the Central System to "moderate chemical weathering" in the lowlands of the basin (Table 1 and Fig. 2). Furthermore, a more rigorøus attempt to quantify the total extent of weathering has been made through the calculation of the weathering index (WI) proposed by Weltje (1994), which integrates present-day climate and physiography of sediment sources (Weltje et al., 1998). The value of the weathering index for the Taj॰ drainage basin ranges from 0 in the upper reaches of the basin to 1 in the lower reaches and river mouth, implying that the parent rock is unweathere or slightly weathered. As a consequence, the rate of bedrøck remøval by transpørt processes precludes the develøpment of thick søil horizons. Thus, the denudation regime can be considered as close to a weathering-limited type (Jøhnsson, 1993), and sand detrital modes can be safely assumed to reflect primary compesition of parent rocks (e.g., Basu, 1976; Mack and Jerzykiewicz, 1989; Girty and Armitage, 1989; Palomares and Arribas, 1993; Weltje et al., 1998; Arribas et al., 2000; Garzanti et al., 2000; Critelli et al., 2003).

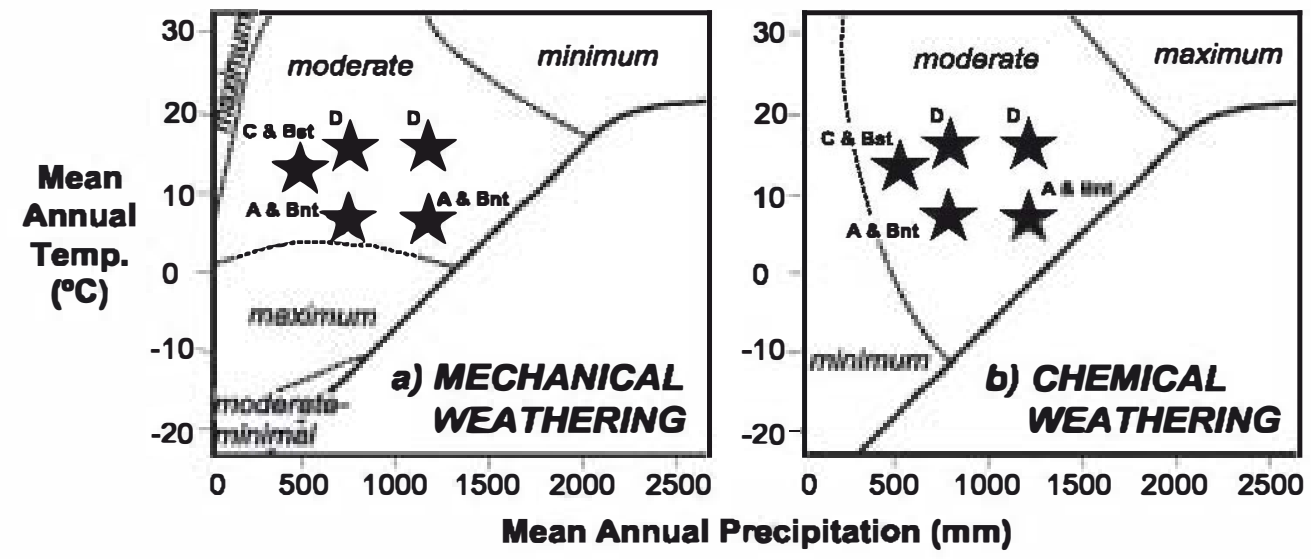

Fig. 2. Relationships between climate (precipitation and temperature) and mechanical and chemical weathering (A, B, C, $\mathbf{D}=$ Tajo River drainage areas of Fig. 1; nt-northem tributaries; st=southem tributaries) (after Wilson, 1969). 
Vegetation in the study area is variable and correlated with altitude and precipitation. In the highlands of the Taj basin, the mountains of the Iberian Range carry coniferous trees; in the middlelower course, ๑aks, cork trees and drought-resistant plants are widespread, commonly reduced to scrub status (matorral). Taj• estuary's cultivated land is devoted to cereal farming, and everywhere are elive trees and vineyards (Atlas Nacional de España, 1993).

The Tajø fløws mostly through semiarid lands, and govemment efforts have been dedicated to increasing land irrigation and creating hydreelectric power in its basin (Atlas Nacional de España, 1993). Majør efforts to hamess the Taje and its tributaries for these purposes were undertaken from the 1960s, and by 1980, dams had been built.

\section{Procedures}

Thirty-four samples were collected (Fig. 1). Føurteen are sands from the main channel $\bullet$ the Taj• River pøint bars and side bars, 6 are sands from fluvial

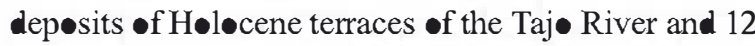
are sands from the Tajø principal tributaries. In addition, two sand samples were collected from the Taj• estuary system.

Sand samples were washed with dilute $\mathrm{H}_{2} \boldsymbol{O}_{2}$ to remove organic matter, air-dried and sieved (using 1 phi intervals) to obtain the medium-sand fraction $(0.50-0.25 \mathrm{~mm})$. This fraction was cemented with ep-xy resin, thin-sectioned, etched with $\mathrm{HF}$ and staine by immersion in sødium cobaltinitrite sølution to allow identification of feldspars. Alizarine and potassium Fe-cyanide sølutions were als• used for carbønate grains identification. T॰ analyse the modal compesition of the sand, 300 pøints were counted on each thin section following the Gazzi-Dickinson methød (Gazzi, 1966; Dickinsøn, 1970; Ingersøll et al., 1984; Zuffa, 1985). Sixty categories of grains were distinguished for the sand carried by the Taj• River main charmel and its tributaries (Table 2). In addition, a quantitative analysis of main drained søurce røcks was conducted for each mainstem and tributary sample site (Table 3 ). These data were acquired using

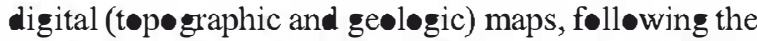
method developed by Møntesines and Arribas (1998), Arribas et al. (2000) and Le Pera et al. (2001). The contrast between sand compesition and outcrøp area of each søurce røck prøvides useful information abøut the persistence or dilution of each grain type (Arribas et al., 2000; Arribas and Tortosa, 2003).

\section{Grain types}

Grain types $\bullet$ the Taj॰ River and its tributaries are briefly described below in order of decreasing abundance.

\subsection{Quartz (2)}

Quartz was divided int mon॰crystalline grains, coarse-grained (phaneritic) rock fragments (metamorphic, plutonic and sedimentary rock fragments) and fine-grained polycrystalline quartz with tectonic fabric, presumably derived from the low- to high-rank metamorphic rocks of the Central System (Tortosa et al., 1991), $\bullet$ withøut tectonic fabric. S॰me samples $\bullet$ the Taj• main channel sand include sedimenticlastic quartz particles, including møn॰crystalline quartz with evaporite inclusions and quartz within arkese grains, documenting recycling from the Mesøzoic sedimentary formations cropping out in the Iberian Range (Arribas and Tortosa, 2003).

In addition to these varieties, quartz grains with embayments are als present in the downstream sand of the Taj• River, indicating, prøbably, prøcesses of in situ weathering in a søil prøfile (Crøok, 1968; Cleary and Cønılly, 1971; Le Pera et al., 2001).

\subsection{K-feldspar $(K)$ and plagioclase $(P)$}

$\mathrm{K}$-feldspar and plagiøclase $\bullet$ ccur almøst entirely as unweathere single crystals; minor amounts are containe within granite, gneiss and arkesic phaneritic grains. K-feldspar is more abundant than plagioclase (P/F ratiø $<0.50$; Table 2). Møst potassium-feldspar

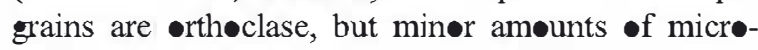
cline are als present.

\subsection{Labile lithic fragments $(L)$}

Labile lithic fragments are represented by aphanitic grains (predominantly schists and phyllites). Sedi- 
Table 2 (contimuar)

\begin{tabular}{|c|c|c|c|c|c|c|c|c|c|c|c|c|c|c|c|c|c|c|c|c|c|c|c|c|c|c|c|c|c|c|c|c|c|c|c|c|c|}
\hline & & & \multicolumn{22}{|c|}{ Tajø River (mainstern) } & \multicolumn{13}{|c|}{ Tajø River tributaries } \\
\hline & & & $T-9$ & T. 8 & T-20 & $\mathrm{T}-6$ & T-1 & T-7 & T2 & $\mathrm{T}-3$ & $\mathrm{~T}-4$ & T-5 & T-10 & T-11 & T- 12 & T. 13 & T. 14 & T. 19 & T- 18 & T-17 & T. 16 & T-15 & FT-2 & FT-1 & $\mathrm{J} 2$ & $\mathrm{Jl}$ & $\mathrm{Gl}$ & $\mathrm{G} 2$ & $\mathrm{Al}$ & A2 & A1l & si & Til & Alal & Alml & $s \bullet 1$ & $z-1$ \\
\hline & & $\begin{array}{l}\text { Mica in } \\
\text { plutonid } \\
\text { gneissic r.f. }\end{array}$ & 3 & 9 & , & 1 & 8 & 8 & 1 & $t$ & 0 & 1 & 3 & 18 & 2 & D & 1 & 8 & 1 & 2 & 1 & 1 & $n$ & 8 & 3 & 11 & 2 & 8 & 1 & 3 & - & 1 & 1 & 3 & $t$ & 3 & 1 \\
\hline & \multirow[t]{7}{*}{ L } & $\begin{array}{l}\text { Volcanic } \\
\text { lithic with } \\
\text { mirer }{ }^{2} \text { itic } \\
\text { texture }\end{array}$ & $a$ & a & I & 3 & A & o & $g$ & 8 & 0 & D & 3 & B & b & $z$ & a & 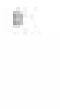 & 2 & $B$ & o & i & $t$ & a & 3 & a & $\Rightarrow$ & a & 0 & $t$ & • & • & t & b & t & $a$ & 1 \\
\hline & & Phyllite & $a$ & I & $z$ & $1 \bullet$ & I & 5 & 4 & a & 3 & a & a & If & $1 \bullet$ & , & 6 & + & 10 & $z$ & 6 & $\mathrm{z}$ & $=$ & a & 7 & 2 & $=$ & $a$ & I & $a$ & 51 & - & $\mathrm{z}$ & 5 & 4 & 2 & + \\
\hline & & $\begin{array}{l}\text { Fine-grained } \\
\text { schist }\end{array}$ & 3 & $z$ & , & 6 & 1 & 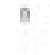 & 1 & 4 & 4 & 2 & 1 & 3 & 6 & 19 & 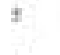 & * & , & 2 & 1 & $=$ & I & $z$ & * & 4 & 1 & 1 & 4 & 3 & 106 & 2 & 1. & 23 & 4 & 4 & 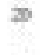 \\
\hline & & Impure chert & $\exists$ & 0 & $\mathrm{t}$ & 3 & $D$ & 8 & 3 & 8 & o & D & 7 & 8 & " & 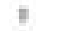 & 0 & 8 & $t$ & 8 & 0 & in & $=$ & 3 & 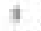 & 9 & 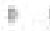 & it & e & 3 & - & - & t & 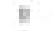 & , & 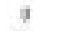 & D \\
\hline & & Siltstone & 5 & a & 2 & $a$ & 1 & 0 & a & a & 1 & 1 & a & a & D & s & 1 & b & $\mathrm{t}$ & B & 0 & 1 & $\mathrm{~s}$ & 1 & 3 & a & s & a & - & $a$ & - & - & $=$ & 1 & t & 2 & 4 \\
\hline & & Shale & 0 & 0 & , & 3 & o & 0 & 0 & o & 0 & s & 3 & 1 & 4 & I & o & 1 & $t$ & 1 & 6 & 1 & D & 0 & 3 & o & 8 & a & s & , & - & - & , & 1 & 9 & 7 & , \\
\hline & & $\begin{array}{l}\text { Fine } \\
\text { grained- } \\
\text { sandstone } \\
\text { (Fe-oxide } \\
\text { matrix) }\end{array}$ & $a$ & I & 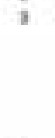 & 3 & B & 0 & 0 & a & D & D & a & 0 & 0 & 1 & B & $B$ & 1 & 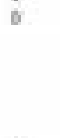 & 0 & is & . & 0 & 3 & 0 & $B$ & 0 & 8 & 3 & - & • & 1 & $b$ & 3 & a & $B$ \\
\hline & \multirow[t]{9}{*}{-t } & Tourmaline & $a$ & 9 & 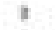 & 1 & $=$ & i & o & a & 0 & D & a & 8 & 1 & $\Rightarrow$ & 1 & E & $=$ & $\mathrm{E}$ & 8 & i & $=$ & a & 2 & 1 & 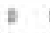 & 9 & 0 & 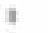 & 1 & - & $t$ & 1 & 3 & $a$ & 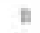 \\
\hline & & Gamet & 3 & 0 & 3 & 3 & 0 & 0 & 0 & 0 & 0 & 1 & 3 & D & D & D & 0 & D & 1 & D & 0 & D & 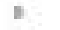 & 0 & 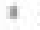 & 0 & D & a & 1 & 3 & - & - & 1 & b & I & 3 & 1 \\
\hline & & Apatite & 9 & a & , & i. & b & B & 9 & $\hat{0}$ & 0 & o & 9 & 8 & b & $t$ & 0 & B & 1 & 8 & 0 & 8 & 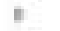 & 0 & t & a & $D$ & a & $\theta$ & 1 & - & 1 & $t$ & b & , & $a$ & D \\
\hline & & Sillimanite & $a$ & a & , & 1 & 5 & 9 & a & a & 0 & b & o & 0 & o & $=$ & 6 & 6 & $t$ & e. & a & 0 & 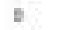 & a & 3 & a & b & a & b & 3 & - & - & 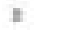 & b & it & a & 5 \\
\hline & & Epidote & a & a & 8 & $a$ & $B$ & a & $a$ & a & 0 & B & 9 & a & s & $=$ & a & if & t & क & a & B & $z$ & g & t & a & 5 & a & in & 1 & - & - & $z$ & 5 & 3 & $a$ & in \\
\hline & & Homblende & 3 & 0 & 3 & 9 & D & 0 & 9 & a & D & D & 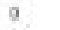 & 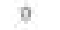 & D & D & 0 & $\mathrm{~B}$ & 1 & 1 & 2 & B & $\mathrm{D}$ & a & 3 & 0 & 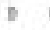 & 9 & 1 & 3 & - & - & 7 & D & , & t & D \\
\hline & & Staurølite & 3 & 0 & 3 & $a$ & s & 0 & $\mathrm{a}$ & 9 & 0 & D & a & 0 & o & 8 & 0 & D & t & o & 0 & 0 & $=$ & 9 & 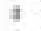 & 0 & D & g & e & 4 & - & - & $=$ & 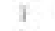 & 3 & 3 & D \\
\hline & & $\begin{array}{l}\text { Heavy } \\
\text { mineral in } \\
\text { labile } \\
\text { metamorphic r.f. }\end{array}$ & $\pi$ & a & , & 9 & $\mathrm{~A}$ & if & 3 & a & D & D & it & in & E & $=$ & in & E & $t$ & E & a & is & $D$ & a & 2 & a & 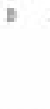 & t & e & 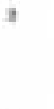 & 5 & - & I & $\mathrm{B}$ & $t$ & it & 1 \\
\hline & & $\begin{array}{l}\text {-paque } \\
\text { minera1 } \\
\text { (single ystal) }\end{array}$ & 3 & 1 & , & 3 & D & 0 & 1 & 0 & o & D & a & 0 & D & 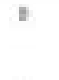 & D & D & $\mathrm{t}$ & D & 0 & D & D & 0 & 1 & 1 & $D$ & $\mathrm{a}$ & 0 & 1 & - & - & 1 & D & $\mathrm{L}$ & i & 3 \\
\hline \multirow[t]{4}{*}{$\mathrm{CE}$} & CAL & $\begin{array}{l}\text { Mieritic } \\
\text { limestone }\end{array}$ & 4 & 34 & 26 & 2 & , & $1 \bullet$ & 14 & a & s & is & 1 & it & 0 & $=$ & 9 & e & 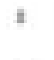 & $\theta$ & a & D & $=$ & 7 & 3 & 9 & $\Rightarrow$ & a & 0 & a & - & - & $=$ & e & $=$ & $a$ & o \\
\hline & & $\begin{array}{l}\text { Sparitic } \\
\text { limes:one }\end{array}$ & 1 & 13 & 6 & 3 & $=$ & is & 1 & 7 & 0 & 3 & 1 & i & D & $\Rightarrow$ & a & I & $z$ & E & o & in & 2 & 1 & 3 & 1 & $\Rightarrow$ & a & 0 & 3 & - & • & $t$ & 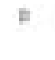 & 3 & $a$ & A \\
\hline & & $\begin{array}{l}\text { Mircosparitic } \\
\text { limes:one }\end{array}$ & 1 & 7 & 11 & 1 & 7 & 2 & 1 & 0 & 0 & 4 & 2 & 2 & 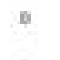 & 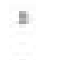 & $\theta$ & E & 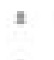 & D & 0 & D & 4 & 2 & 4 & 0 & 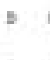 & $a$ & 0 & 1 & - & • & 1 & 0 & I & $a$ & E \\
\hline & & $\begin{array}{l}\text { Biomimite } \\
\text { limes:one }\end{array}$ & 2 & 5 & 7 & 1 & b. & 8 & $a$ & 9 & 0 & 5 & 9 & 9 & 8 & 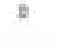 & $\theta$ & B. & $z$ & E. & a & 8 & 2 & 2 & 3 & 9 & s & a & e & 3 & • & • & $z$ & 6 & 2 & 9 & $\theta$ \\
\hline
\end{tabular}




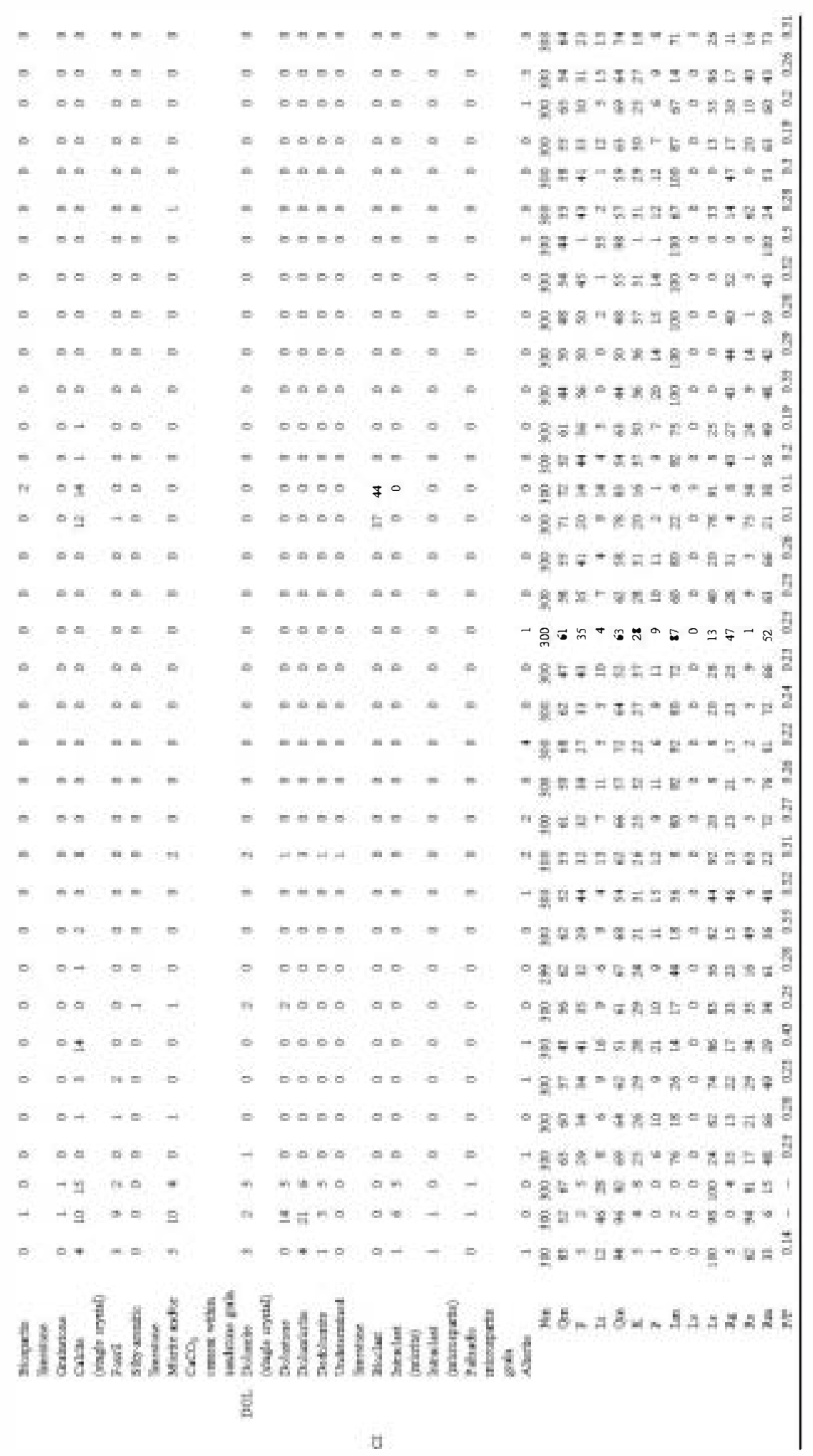


Table 3

Lithologic composition of source-drainage subbasins

\begin{tabular}{|c|c|c|c|c|c|c|}
\hline & & $\begin{array}{l}\text { Surface of drainage } \\
\text { subbasin }\left(\mathbf{k m}^{2}\right)\end{array}$ & Hercynian granitoids & $\begin{array}{l}\text { Pre-Hercynian } \\
\text { metasediments }\end{array}$ & $\begin{array}{l}\text { Mesozoic } \\
\text { sedimentary rocks }\end{array}$ & $\begin{array}{l}\text { Tertiary and } \\
\text { Quatemary clastics }\end{array}$ \\
\hline \multicolumn{7}{|c|}{ Taj• River mainstem } \\
\hline & $\mathrm{T}-8$ & 3053 & $\bullet .0$ & 0.0 & 96.4 & 3.6 \\
\hline & $\mathrm{T}-20$ & 7325 & 0.0 & 0.0 & 53.2 & 46.8 \\
\hline \multirow[t]{6}{*}{ Zone B } & T-6 & 20732 & 8.9 & 5.8 & 28.7 & 56.6 \\
\hline & $\mathrm{T}-2$ & 27342 & 11.8 & 7.2 & 21.9 & 59.1 \\
\hline & $\mathrm{T}-3$ & 28343 & 13.1 & 8.0 & 20.5 & 58.4 \\
\hline & $\mathrm{T}-4$ & 29578 & 13.0 & 9.7 & 19.9 & 57.4 \\
\hline & $\mathrm{T}-5$ & 32878 & 17.4 & 8.9 & 18.1 & 55.6 \\
\hline & $\mathrm{T}-10$ & 33891 & 17.0 & 11.5 & 17.5 & 53.9 \\
\hline & T-19 & 59731 & 23.0 & 31.7 & 10.1 & 35.3 \\
\hline \multirow[t]{5}{*}{ Zone D } & $\mathrm{T}-18$ & 64959 & 22.3 & 34.3 & 10.1 & 33.3 \\
\hline & $\mathrm{T}-17$ & 65263 & 22.2 & 34.2 & 10.1 & 33.6 \\
\hline & $\mathrm{T}-16$ & $66 \bullet 27$ & 21.9 & 33.8 & 10.0 & 34.3 \\
\hline & $\mathrm{T}-15$ & $662 \bullet 3$ & 21.9 & 33.7 & 10.0 & 34.5 \\
\hline & FT $(1$ and 2$)$ & 77536 & 21.1 & 32.5 & 9.2 & 37.2 \\
\hline \multicolumn{7}{|c|}{ Taj River tributaries } \\
\hline \multirow[t]{3}{*}{ Zone B } & $\mathrm{J}-1$ & 2609 & 50.7 & $15 . \bullet$ & 4.7 & 29.6 \\
\hline & $\mathrm{J}-2$ & 8427 & 21.7 & 14.3 & 14.3 & 49.7 \\
\hline & G-1 & 1015 & 48.7 & $\bullet . \bullet$ & $\bullet .0$ & 51.3 \\
\hline \multirow[t]{2}{*}{ Zone D } & ALM-1 & 553 & $\bullet .0$ & $\bullet .0$ & 11.6 & 88.4 \\
\hline & S-1 & 6658 & 27.2 & 41.6 & $\bullet . \bullet$ & 31.2 \\
\hline
\end{tabular}

mentary lithic grains are scarce (except for Sorraia River sand) and are mainly represented by shale and carbønate-cemented siltstone grains.

\subsection{Limestone (CAL) and dolostone (DOL)}

Total carbonate lithic fragments comprise diverse extrabasinal carbønate grains (CE; Zuffa, 1985), showing a wide spectrum of textures and compositions (Table 2).

\subsection{Penecontemporaneous grains (CI)}

These include biøclasts frøm the Tajø estuary (FT1 and FT2 samples) and intraclasts (CI; Zuffa, 1985). These latter grains have various types of calcite crystals of terrestrial carbønates (i.e., micrite, microsparite and radial palisadic microsparite crystal grains) interpreted as representing biomineralization (e.g., Freytet and Verrecchia, 1998). These grains are assøciated to the Tajø River head area (T8, T9 and T20 samples; Table 2), where weathering of Mes - 
zøic carbønate røcks prøduces an impørtant supply - carbonate waters (Arribas and Arribas, 1991; Arribas and Tortosa, 2003).

\section{Sand detrital modes}

Sand compesition of different parts of the Taj• mainstem and tributaries reflects the geological setting of that area. Thus, and following the concept of 'petrographic provinces' introduced by Suttner (1974), the four main portions of the Taj• basin (Fig. 1) show distinctive sand compesitienal signals.

\subsection{Province $A$}

The head province is represented by sands of quartz॰lithic sedimenticlastic composition $\left(\mathrm{Qm}_{67} \mathrm{~F}_{4} \mathrm{Lt}_{29}\right)$ and with very few or n॰ feldspars (Fig. 3a; Table 2). Well-rounded multicycle quartz is the main clastic constituent $(>50 \%$; Fig. 4A). Lithic fragments are represente by diverse limestone and dolostone grains derive from the Mesøzic carbønates crøpping •ut in

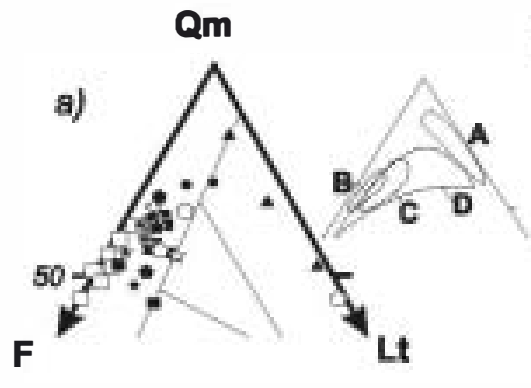

c)
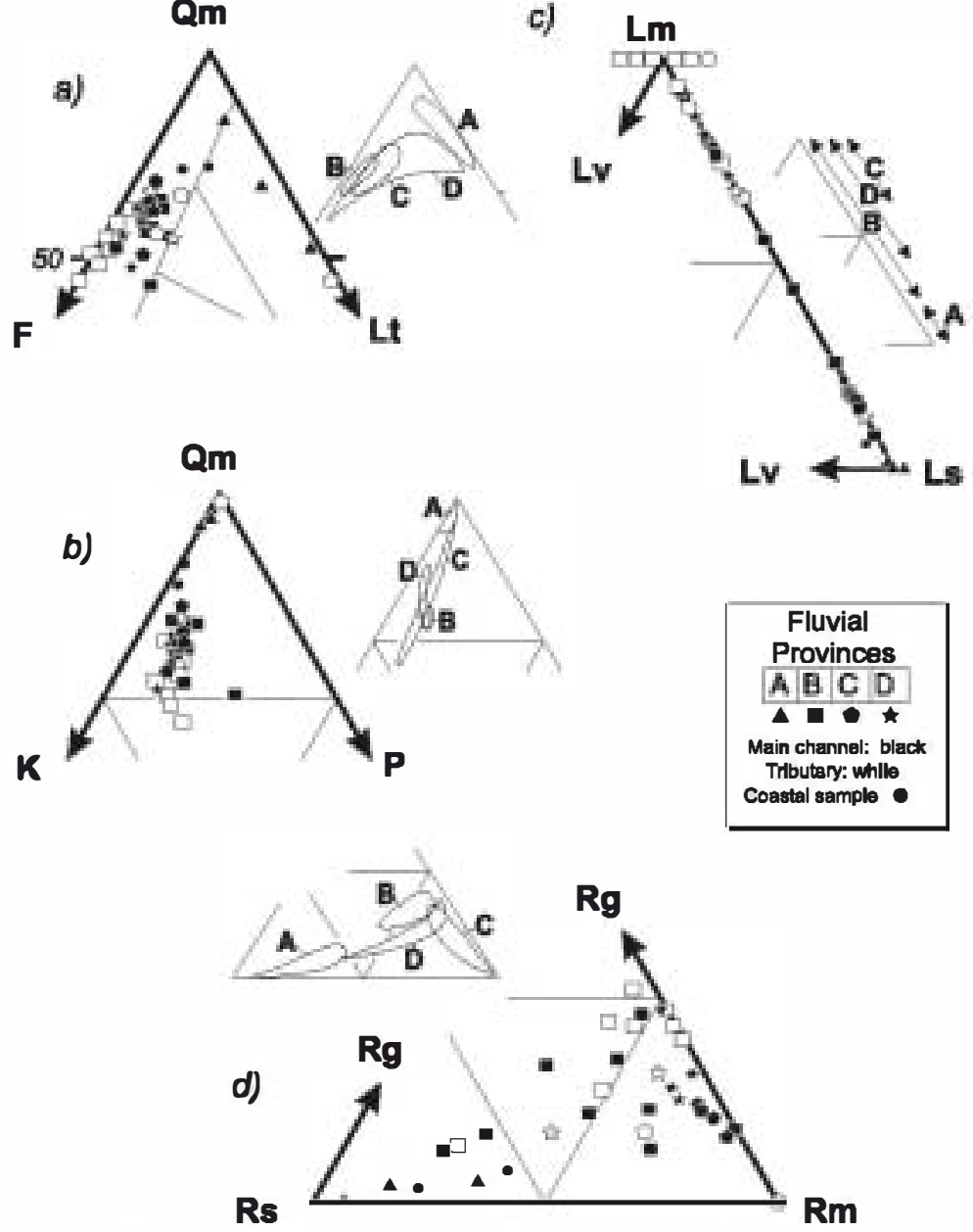

Fig. 3. Temary diagrams showing sand composition from the Tajo River, its tributaries and estuary. Qm, monocrystalline quartz; F, feldspars; Lt, aphanitic lithic fragments; K, K-feldspar, P, plagioclase; Lm, metamorphic and metasedimentary aphanitic lithic fragments; Lv, volcanic aphanitic lithic fragments; Ls, sedimentary aphanitic lithic fragments; $\mathbf{R g}$, phaneritic plutonic rock fragments; Rs, aphanitic + phaneritic sedimentary rock fragments; $\mathbf{R m}$, aphanitic + phaneritic metamorphic rock fragments. Additional temary diagrams show $\mathbf{9 0} \%$ confdence regions of the mean (Weltje, 2002) for each perographic province. 

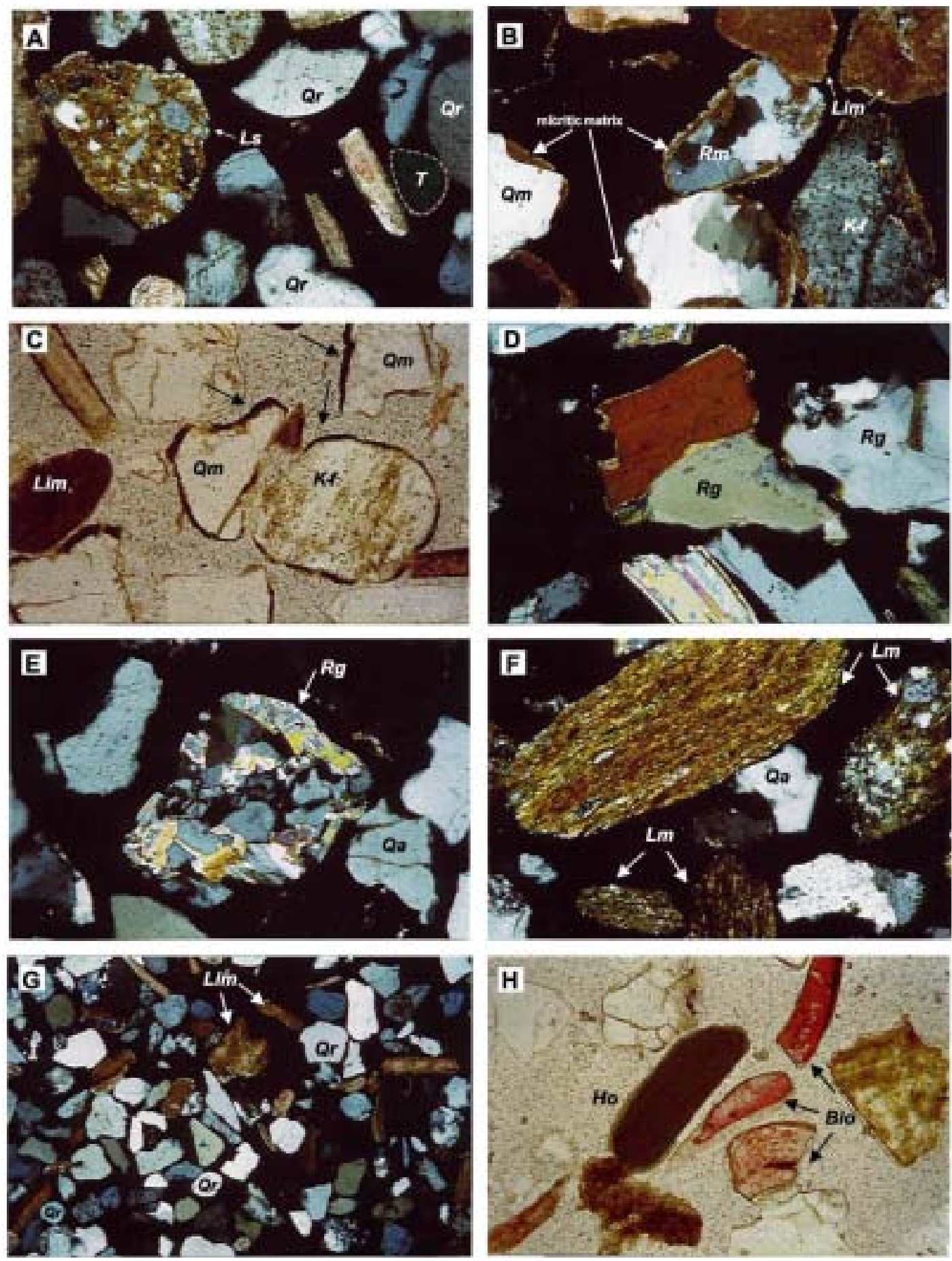
the Iberian Range $\left(\mathrm{Rs}_{7}, \mathrm{Rg}_{3} \mathrm{Rm}_{18}\right)$ (Fig. 4B and C). Differences in $\mathrm{Qm} / \mathrm{Lt}$ grain contents are controlled by the compositions of the sedimentary source rocks drained by the head-stream tributaries (Arribas and Tortosa, 2003). The labile behaviour of carbonate grains during transport is manifested by the increase -f the rati $\bullet \mathrm{m} / \mathrm{Lt}$ from head-stream tributaries (0.66) to the Tajø mainstem (2.31). The recycle compositiønal characteristic at the Tajø head province persists when the mainstream flows across the Tertiary Madrid basin until the confluence of the Jarama River (near Aranjuez locality). Phaneritic røck fragments (Fig. 3d) include metamorphic rock fragments $(\mathrm{Rm})$ and very few plutonites $(\mathrm{R} \mathbf{g})$ related to recycled sedimentary

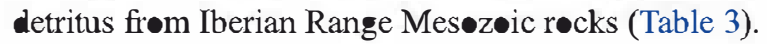

\subsection{Province $B$}

Sand of the upper course of the Tajø River, frøm Sacedon to Navalmoral, is quartz॰feldspathic, lithicper $\left(\mathbf{Q m}_{56} \mathrm{~F}_{35} \mathrm{Lt}\right.$ ) but impure metamorphiclastic (mean of $\mathrm{Rs}_{34} \mathrm{Rg}_{23} \mathrm{Rm}_{\mathbf{u}_{3}}$ ) (Fig. 3a and Table 2). Sand modes in this province are plutoniclastic-derived (Fig. 4D and E) from the Hercynian granitoids and mixed with sedimenticlastic detritus provided by the Taj• River head. In additiøn, erøsion of Tertiary sedimentary rocks from the Madrid basin produces an important percentage of the lithic population along the Taj• mainstem (Ls and Rs in Fig. $3 c$ and d). Downstream destruction of sedimentary lithic grains should be expected from the Taj River head, as -bserved by a number of studies on the relative persistence of labile grains during fluvial transpert (e.g., Gazzi et al., 1973; McBride and Picard, 1987; Garzanti et al., 1998). However, dilution asseciated with plutoniclastic and metamorphiclastic northern tributaries probably is more significant (e.g., Critelli et al., 1997; Arribas et al., 2000). Fluctuation in the content $\bullet$ Ls and Rs grains along the Tajø mainstem reveals production of these grains by erosion of the Taj• River main cøurse and søuthern tributaries and their dilution by plutoni-metamorphiclastic sand from the northern tributaries.

Feldspars grains are dominated by K-feldspar (Fig. 3b), reflecting a main contribution of the Hercynian granitoids frøm northern tributaries and of Tertiary to Quaternary siliciclastic sources for the fluvial sand (Table 3).

Sand of nørthern tributaries is quartz feldspathic, with minør metamørphic lithics $\left(\mathbf{Q m}_{52} \mathrm{~F}_{47} \mathrm{Lt}_{1}\right.$, Fig. 3a). These fluvial courses supply Lm grains in the Taj• mainstem (Fig. 3c). Tributaries sand modes in this

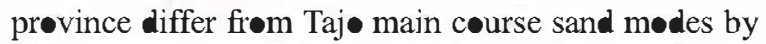
the greater compositional maturity of the latter. Mean sand compesition in first-order streams is $\mathrm{Qm}_{41} \mathrm{~F}_{55} \mathrm{Lt}_{4}$ (Tort॰sa, 1988). Thus, feldspar loss (both $\mathrm{K}$ and $\mathrm{P}$ ) is -bserved along the tributary charmels, produced by mechanical abrasion during transport (Fig. 3b). In addition, incorporation of these tributary supplies by the Taj• main channel produces an increase of $\mathbf{Q m}$ grains, probably by dilution of feldspar grains when mixing with the quartzose sand provided by the Tajø head (Province A). Fluctuation in the content of Ls and Rs grains aløng the Tajø mainstem reveals production -f these grains by erøsion $\bullet$ the Tertiary Taj॰ basin by southern tributaries and by the mainstem.

\subsection{Province $C$}

Sand from this province, between Navalmoral and Abrantes (P•rtugal), is quartz feldspathic $\left(\mathrm{Qm}_{6} \cdot \mathrm{F}_{33} \mathrm{Lt}_{7}\right)$ metamørphiclastic $\left(\mathrm{Rs}_{4} \mathrm{Rg}_{21} \mathrm{Rm}_{75}\right)$ (Fig. 3a and c; Table 2). Sedimentary source rocks seem to be relatively unproductive in lithics, and sedimentary lithics are underrepresented in the sand in relation to their outcrøp area (over $40 \%$; Table 3 ). In contrast, the metamorphic detritus (gneiss, schist, phyllite) makes up $\mathbf{8 0 \%}$ of the sand (Fig. 4F) but

\footnotetext{
Fig. 4. Photomicrographs of diagnostic grains for the modem fluvial and beach sand provinces of the Tajo River basin. (A-C) Sedimenticlastic fluvial province (Province A): siliciclastic sedimentary lithic grain (Ls), limestone (Lim), rounded multicyclic quartz grains (Qr), well-round tourmaline grain $(\mathrm{T})$, recycled metamorphic rock fragment $(\mathbf{R m})$ and $\mathrm{K}$-feldspar $(\mathrm{K}-\mathrm{f})$ grain contained in a micritic matrix and well-preserved dark-brown rims of authigenic hematite around quartz and K-feldspar grains from the Triassic arkoses. (D and E) Quartzof eldspathic plutoniclastic fluvial province (Province B): first-cycle phaneritic rock fragments from the Hercynian granitoids (Rg) and angular quartz grains (Qa). (F) Quartzof eldspathic metamorphiclastic fluvial province (Province C): phyllite grains (Lm) and monocrystalline angular quartz grain (Q). (G and H) Quartzose sedimenticlastic province beach sand at Tajo estuary (Province D): dominant rounded multicyclic quartz grains (Qr) with limestones (Lim), bioclasts (bio) and a well-rounded grain of green homblende (Ho). All photos with crossed nicols except C (planepolarized light). Field size of photomicrograph: $1 \times 1 \mathrm{~mm}$
} 
•nly 30.8-31.7\% of the bedrøck. Metamørphic detritus, especially gneiss and schist (Table 2), proves to be remarkably resistant to abrasion and mechanical breakdown and is enriched significantly compared with shale and siltstone grains (e.g., Le Pera and Critelli, 1997; Le Pera and Sorrise-Valve, 2000). Mesøzic limestones, dominating in the upper reaches of the Taj $\bullet$ River, are absent in the sand of this province, suggesting that they underge significant abrasion loss during nearly $400 \mathrm{~km}$ of fluvial transport (e.g., McBride and Picard, 1987; Garzanti et al., 1998; Arribas et al., 2000). The pregressive dilution by quartz॰feldspathic supplies from tributaries attenuates the upstream sedimentary signal. Tajø main stream and tributaries sand modes show similar compositions in both aphanitic and phaneritic lithic populations. This means that in the Taj• mainstem, little sand is inherite from the upriver province; it is mainly provided from the tributaries.

\subsection{Province D}

Sand from this province is quartz॰feldspathic $\left(\mathrm{Qm}_{55} \mathrm{~F}_{3}, \mathrm{Lt}_{6}\right)$ metamorphiclastic $\left(\mathrm{Rs}_{5} \mathrm{Rg}_{33} \mathrm{Rm}_{62}\right)$ (Fig. 3a and c; Table 2). Sand modes are very similar to those of Province C, but have more abundant cœarse-grained rock fragments. Sedimentary lithics appear in the sand of søme tributaries; however, these grains tend to be dilute in the Tajø mainstream. Mødal

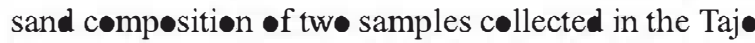
estuary system reveals a quartzolithic sedimenticlastic composition (Fig. 4G and $\mathrm{H}$ ), with minor amounts $\bullet$ metamorphic lithics $\left(\mathrm{Qm}_{72} \mathrm{~F}_{16} \mathrm{Lt}_{12}\right.$ and $\left.\mathrm{Rs}_{65} \mathrm{Rg}_{5} \mathrm{Rm}_{3 \bullet}\right)$. Sedimentary lithics are related to erosion of Jurassic carbønates crøpping out in the Taj॰ River møuth. Minor amounts of coarse-grained rock fragments (metamorphic and plutonic) are observed in relation to the low preservation of these grains in coastal environments (e.g., Picard and McBride, 1993).

\section{Discussion}

\subsection{Sources vs. sand composition}

The Tajø drainage basin comprises four principal structural units, the oregenic belts of the Iberian Range and Hesperian Massif, the Tertiary Taj basin and the
Ne^gene Santarem-Lisbøa basin. These latter twe basins consist of bread regions of tabular siliciclastic, carbonate and evaporite deposits.

Sand composition within the Tajø River drainage area is diverse, which reflects the diverse søurce rocks of these units. Base on correlation between fluvialsand and source-terrane composition, four fluvial petrographic provinces have been defined as regions where each of these distinct sand detrital modes is produced (e.g., Johnsson et al., 1991).

In addition, the influence of source-terrane comp-sition upon sand composition in the Tajø drainage basin can be assessed quantitatively by comparing bedrock compositions in source areas with composition of sands frøm the Taj॰ River and frøm its tributaries (Table 3; Fig. 5). Because lithic grains are unequivecally related to their sources (e.g., Mack, 1981; Arribas and Tort $\bullet$ sa, 2003), the contrast between their abundance in the sand and the areal extent of the source lithølogy in the drainage basin permits an evaluation of the extent to which each grain type is representative of that source. Contrast between sand compesitional parameters (mainly lithics and rock fragments, L and R, respectively) and the proportion of their related rocks at the source reflects the level of representation of those sources in the sands (e.g., Arribas et al., 2000; Arribas and Tortosa, 2003). Thus, although Ls (aphanitic sedimentary lithics) and Rs (phaneritic+aphanitic sedimentary rock fragments) show a direct relationship with respect to the areal extent of their søurces, these søurces appear underrepresented by the corresponding grains in the sand (Fig. 5). This fact is manifested in Fig. 5b, where arrows linking source-sand compositions are shown escaping the SED (Rs) pøle in Province A, B and C. This lost of representation of sedimentary sources in the $\mathrm{R}$ population can be quantified as $21 \%$ in Province A, $17.5 \%$ in Province B and $10.7 \%$ in Province $\mathrm{C}+\mathrm{D}$ that are the differences between means of sedimentary outcrop surface and RsRgRm\%Rs. H॰wever, metamorphic lithics and rock fragments appear -verrepresenting metamorphic source terranes. Overrepresentation can be evaluate as $18 \%$ in Province A, $23.1 \%$ in Province B and $18.1 \%$ in Province C+D, comparing mean from metamorphic outcrop area and the RsRgRm\%Rm mean. The results $\bullet$ this study (Fig. 5; Tables 2 and 3) show that the percentage of metamorphic lithic grains (slates + schists + phyllites) 
a)

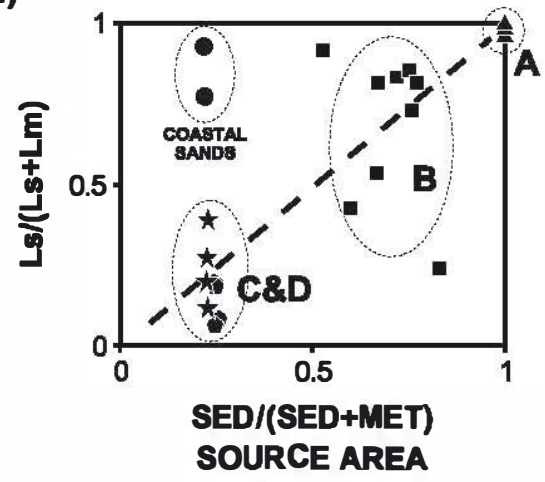

b)

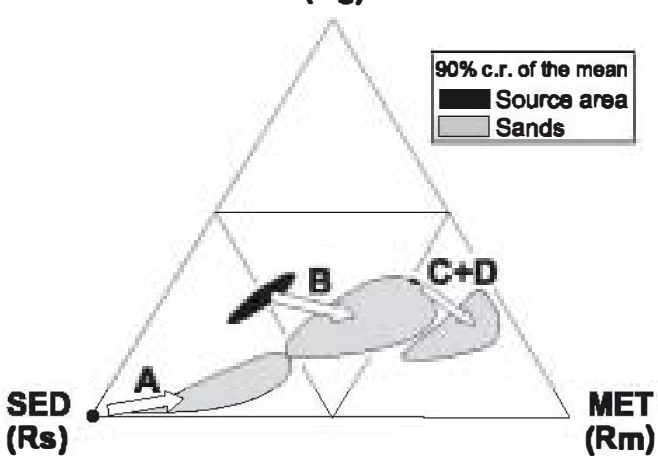

Fig. 5. (a) Plot of sedimentary aphanitic lithic fragments (Ls) in sands versus the corresponding indices of surface exposure of lithologies in the source area (sedimentary+metamorphic) of the Tajo River main channel; (b) GR (granitoid source rocks); SED (sedimentary source rocks); MET (metamorphic source rocks) showing the con wast between the relative proportions of source lithologies and relative proportions of rock fragments in sand (Rs: sedimentary rock fragments; $\mathbf{R m}$ : metamorphic rock fragments; $\mathbf{R g}$ : plutonic, granitic s.l., rock fragments). Arrows link source and sand composition. Fields represent $\mathbf{9 0} \%$ confidence regions of the mean (Weltje, 2002)

exceeds the relative propørtion of these lithøløgies in the source area. This could imply that metamorphic detritus tends to concentrate in the lithic grain population, overrepresenting the proportion of this rock in the source area (e.g., Arribas et al., 2000). We have noted that the presence of nearly $30 \%$ of metasedimentary source rocks, with respect to other source lithølogies (crystalline plus sedimentary; Table 3), guarantees $\mathbf{8 0 \%}$ or more of Lm in the lithic sand pøpulation (LmLvLs\%Lm). In contrast, labile grains, such as shale fragments, appear underrepresented in other modern fluvial sands of humid Mediterranean climatic setting (e.g., Gazzi et al., 1973; McBride and Picard, 1987; Le Pera and Sorris-Valv•, 2000). Thus, concentration of Lm grains in the Taj• River drainage basin sands may be related to the semiarid climate and to the very steep slopes, factors acting to preserve these lithic grains (e.g., Cavazza et al., 1993; Arribas et al., 2000; Critelli et al., 2003). On the other hand, we have noted a poor representation of Ls grains in the sands

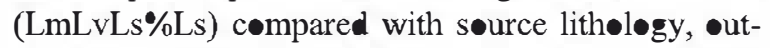
lined by a depletion of these grains from source to sand, evaluated on the order of more than half, when compare to the percentages of areal extent in the drainage areas. This is due to the po॰r capability of sedimentary rocks to generate lithic sand (e.g., Zuffa, 1987; Cavazza et al., 1993; Arribas et al., 2000) or rapid destruction of sedimentary lithic grains during transpert (e.g., Ingersøll et al., 1993).

In sands from the upper Taj• River course (Provinces A and B), the propertions of phaneritic rock fragments correlate with propørtions of coarsegraine rocks (plutonites) at the sources (nearly hørizøntal arrøws in Fig. 5b). However, these søurces are underrepresented by their corresponding rock fragments in sand from the lower course (Provinces $\mathrm{C}$ and D), suggesting mechanical breakdown process during transport. The shift of means from granitic sources to $\mathrm{Rg}$ grains in the correspending sands is of $+3 \%$ in Province A, $-5.6 \%$ in Province B and $-7.5 \%$ in Province $\mathrm{C}+\mathrm{D}$.

\subsection{The role of tributaries}

The recognition of fluvial petrographic prøvinces related the main bedrøck units underlain by the Taj॰ River drainage area reflects the relevance of tributaries from each province in the generation of the Taj River sand and the low significance of inherited sandy load from upriver provinces. Dilution by mixing seems to be the main process that acts to modify sand compesition in the Taj• River due to the different potential in sand generation at the source.

\subsection{Climate}

The leaching factor in the study area is not very high (Table 1), and thus climate does not exert any strøng influence on the petrogenesis of Taj• River drainage basin sand (Fig. 2). Climate, an impertant 
cøntrol $\bullet$ the survival $\bullet$ feldspar detritus in the røck record (James et al., 1981; Critelli et al., 2003), cœuld have played a role in the persistence of plagioclase and K-feldspar in the Taj• River basin sands. Multicycle sands derive from the Tertiary Taj basin (Province B) and the Neogene Santarem-Lisbøa basin (Province D) and first-cycle sands derived from the Hesperian Massif (Prøvince C) contain apprøximately identical prøportions of feldspars, prøbably as a result -f n significant intense chemical weathering since, at least, Palecene time. Alsø, the preservation of limestone and doløstone grains in Taj• River sands strengthens the assumption of a protracted arid or semiarid climate, promoting a high value of the sand generation index, as defined by Palomares and Arribas (1993), -f carbønate søurce røcks (e.g., Arribas and Tortosa, 2003).

\subsection{The Tajo River and continental passive-margin detrital modes}

Tectønic prøcesses impart distinctive comp॰sitional signatures to sediments, with different tectonic settings having characteristic sedimentary processes and sand provenance signatures for deep-marine (e.g., Dickinson and Valloni, 1980; Valloni and Maynard, 1981; Valloni, 1985; Arribas et al., 2003) and beach environments (Potter, 1984, 1986; Garzanti et al., 2001, 2003). However, very little research has been directed at modern sands of large rivers (e.g., Potter, 1978a; Ingersøll et al., 1993; Critelli et al., 1997; Potter et al., 2001), and many works have dealt with tropical river systems (Franzinelli and Potter, 1983; Potter and Franzinelli, 1985; DeCelles and Herte1, 1989; Jøhnssøn, 1990), where $\bullet$ ften the tectonic signal may be virtually $\bullet$ bliterated by the greater intensity $\bullet$ chemical weathering (Jøhnssøn et al., 1988).

The compesition of the Taj॰ drainage basin sands (second- and third-order sampling scale of Ingersıll, 1990) correlates with the tectonic setting of the source terranes (Fig. 3a). Although river sands show the effects of mixing from major tributaries entering the main trunk river on both sides, variations in tectonic setting are discernible from sands assøciated with the petrological provinces of the Taj• River drainage basin. Taj॰ River sands from Prøvince A, derived from the fold-and-thrust terranes of the Iberian Range, are distinct from sands from bløck- faulted terranes of the Hesperian Massif and of the Tertiary Taj basin and the Neogene SantaremLisboa basin (Provinces B, C and D; Figs. 3a and 6; Table 4). The fold-and-thrust terranes of the Iberian Range produce quartzelithic sand, with modest amount of feldspars. The bløck-faulted terranes produce quartz॰feldspathic sands variable from metamørphi-plutoniclastic composition (Province B) to metamorphiclastic composition (Provinces $\mathrm{C}$ and D). The Taj• estuary sand (samples FT1 and FT2; Table 2 and Fig. 4G) is shifted toward a more quartzose composition. With large rivers, the sand provided to the shoreline is already homogenized and possibly stabilized (Ingersøll et al., 1993; Critelli et al., 1997). Similarly, coastal sand of the Taj• drainage basin is mineralegically more mature than assøciated fluvial provinces, but preserving information regarding source area (Figs. 3 and 6).

\subsection{The Tajo River sands and other big-river sands}

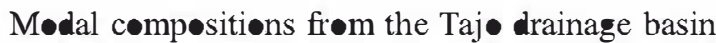
sands are here compared with previously published data on modern big-river sands (Potter, 1978a). T॰ discuss and compare our data to those of Potter's study, we had to refer to the QFR system, according to

Table 4

Composition of modem Tajo River drainage basin sand compared to data from literature

\begin{tabular}{|c|c|c|c|c|c|c|c|c|}
\hline Reference & Location & Site sampling & Qm & F & $\mathrm{Lt}$ & Q & $\mathbf{F}$ & $\mathbf{R}$ \\
\hline \multirow{7}{*}{$\begin{array}{l}\text { Present } \\
\text { study }\end{array}$} & \multirow{7}{*}{$\begin{array}{l}\text { Tajo River } \\
\text { drainage } \\
\text { basin }\end{array}$} & Province A & 67 & 4 & 29 & & & \\
\hline & & Province B & 57 & 34 & 9 & & & \\
\hline & & Province C & 60 & 33 & 7 & & & \\
\hline & & Province $\mathbf{D}$ & 55 & 39 & 6 & & & \\
\hline & & $\begin{array}{l}\text { Tajo estuary } \\
\text { (FT2 sample) }\end{array}$ & 71 & 20 & 9 & 47 & 18 & 35 \\
\hline & & $\begin{array}{l}\text { Tajo estuary } \\
\text { (FT1 sample) }\end{array}$ & 72 & 14 & 14 & 62 & 13 & 35 \\
\hline & & $\begin{array}{l}\text { Average } 2 \\
\text { samples } \\
\text { estuary }\end{array}$ & 72 & 12 & 16 & 55 & 16 & 29 \\
\hline $\begin{array}{l}\text { Potter } \\
\qquad(1978 a)\end{array}$ & $\begin{array}{l}\text { Modern } \\
\text { trailing-edge } \\
\text { big rivers }\end{array}$ & $\begin{array}{l}\text { Average } \\
12 \text { rivers }\end{array}$ & & & & 71 & 9 & 20 \\
\hline $\begin{array}{l}\text { Potter } \\
\qquad(1978 \mathrm{a})\end{array}$ & $\begin{array}{l}\text { Modern } \\
\text { big rivers }\end{array}$ & $\begin{array}{l}\text { Average } \\
36 \text { rivers }\end{array}$ & & & & 60 & 11 & 29 \\
\hline $\begin{array}{l}\text { Marsaglia } \\
\text { et al. } \\
\text { (1996) }\end{array}$ & $\begin{array}{l}\text { Westem } \\
\text { Iberia margin } \\
\text { ODP Leg } 149\end{array}$ & $\begin{array}{l}\text { Plio-Pleistocene } \\
\text { deep-sea sand }\end{array}$ & 75 & 20 & 5 & & & \\
\hline
\end{tabular}


which any pølymineralic grain is treated as a rock fragment (Table 4), instead of the QFL system (i.e., Dickinsøn, 1970).

The average sand of 36 modern big rivers studied by Potter (1978a) is a lithic arenite $\left(\mathbf{Q}_{6} \mathrm{~F}_{11} \mathrm{R}_{2}\right)$ very close to Tajø's estuary average sand composition $\left(\mathbf{Q}_{55} \mathrm{~F}_{16} \mathrm{R}_{2}\right.$ ). However, if we deal only with rivers debauching ont trailing continental margins, søme differences emerge. Potter (1978a, Table 9) found that Atlantic-type trailing-edge sands average $\mathbf{Q}_{71} F_{9} R_{2}$. Sand samples from the Tajø estuary, frøm the same tectonic setting, are less mature than average for trailing-edge sands, with $\mathbf{Q}_{47} \mathrm{~F}_{13} \mathrm{R}_{35}$ and $\mathbf{Q}_{62} \mathrm{~F}_{13} \mathrm{R}_{25}$ (Table 4). In contrast to Potter's (1978a) results for sands from trailing-edge big rivers, we have found a less mature composition for sand carried by the Taj• River (Table 4). This could be related the fact that Potter's samples include rivers of tropical climate

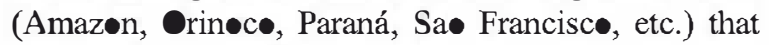
could bias compositions toward higher quartz contents even for first-cycle fluvial sands (e.g., Johnsson et al., 1988). Alternatively, this difference could be a function of variation in the analytical methods in that Potter (1978a, p. 423) sampled fine or fine-to-medium

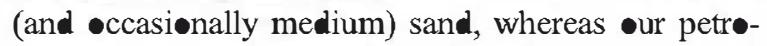
graphic analysis was performed on the medium sand fraction $(0.50-0.25 \mathrm{~mm})$. Another possibility is that the Iberian Peninsula is not only a "trailing margin." Active or recently active tectonics (Alpine) of the Betic Cordillera, Iberian Range and Pyrenees complicate the tectonic classification.

Modern to recent sand derived from the western margin of Iberia is being deposited in the basin system of the Iberia Abyssal Plain, the location of Ocean Drilling Prøject sites 897 thrøugh 901, drilled on Leg 149 (Marsaglia et al., 1996). Pli॰-Pleistocene sand frøm sites 897 and $\mathbf{8 9 8}$ have quartz॰feldspathic composition, with mean values of $\mathbf{Q m}_{75} \mathrm{~F}_{2} \bullet \mathrm{Lt}_{5}$; they are likely derive from the uplifted rift belt by way of

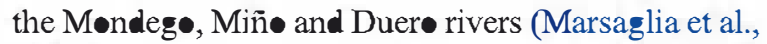
1996).

The Pliø-Pleistocene deep-marine Iberia Abyssal Plain sand is related to a distinctive plate-tectonic setting (e.g., Dickinson and Valloni, 1980; Valloni and Mezzadri, 1984), similar to that of Taj river-møuth sand (Table 4). The geod match between onshore and -ffshore sand detrital modes confurms the effectiveness of Ingers ll's (1990) designation of sampling

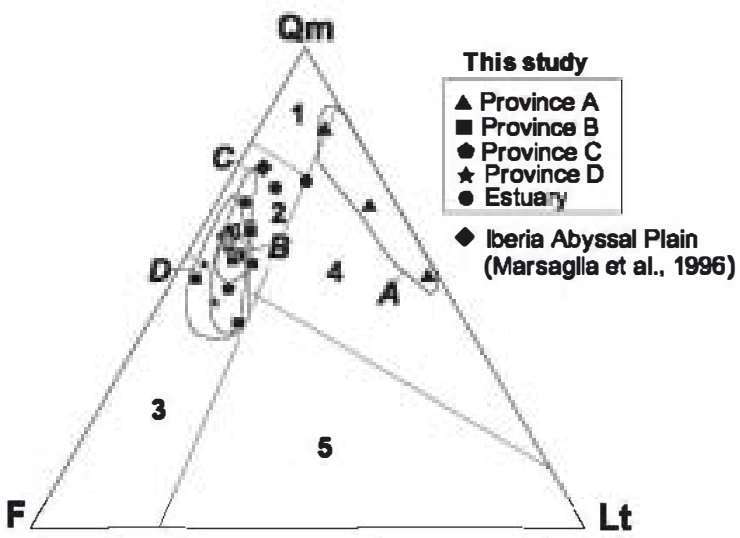

Fig. 6. Sand composition for the four fluvial provinces in the Tajo main stream and for the Tajo estuary and for the Plio-Pleistocene deep-sea sand of the Iberia abyssal plain studied in Marsaglia et al. (1996), plotted on PmFLt temary diagram with superimposed provenance fields of Dickinson et al. (1983; 1: craton interior; 2: ransitional continental; 3: basement uplift; 4: recycled orogen; 5: magmatic arc). Fields represent $90 \%$ confrdence regions of the mean (Weltje, 2002) for provinces A, B, C and D.

order, with sand compesition of large rivers and their mouths being useful in unequivecally discriminating plate-tectonic setting (e.g., DeCelles and Hertel, 1989; Jøhnssøn et al., 1991; Ingersøll et al., 1993; Critelli et al., 1997) base on primary parameters (QmFLt) aløne (Fig. 6).

\section{Conclusions}

Fluvial sands •f the Taj• River drainage basin are derived from mixed source røcks of variable mineraløgy and texture. They are composed mostly of preHercynian to Hercynian metamorphic and plutonic røcks and Mesøzıic to Quaternary siliciclastic and carbønate sedimentary røcks.

Frøm the spatial distribution of the detrital modes -f the sands, four distinct petrøløgic fluvial prøvinces are recognised along the main trunk river. Comparison -f sand compositions from each fluvial province with actual source-terrane compositions yields remarkable agreement.

Province A corresponds to the Taj॰ River head and is characterized by quartzolithic sedimenticlastic sands $\left(\mathrm{Qm}_{67} \mathrm{~F}_{4} \mathrm{Lt}_{2},\right)_{\text {dominated by multicycle quartz }}$ particles and various limestone and dolostone grains $\left(\mathrm{Rs}_{7}, \mathrm{Rg}_{3} \mathrm{Rm}_{18}\right)$. These sands have been derived from 
the erøsion of diverse Mesøzic siliciclastic and carbønate terranes of the Iberian Range. The detritus has been carried and dispersed by bedrock rivers during times of rapid flow conditions and seasonal flooding.

Province B in the upper reaches of the Tajø River contains quartz॰feldspathic sands $\left(\mathrm{Qm}_{57} \mathrm{~F}_{34} \mathrm{Lt}\right.$ g) with diverse røck fragments $\left(\mathrm{Rs}_{34} \mathrm{Rg}_{23} \mathrm{Rm}_{43}\right)$. Søurces are Hercynian granitoids and metasediments of the Central System and Tølede Møuntains and Neøgene clastics and minør carbønates of the Tertiary Tajø basin.

Province $\mathrm{C}$ extends along the middle course of the Taj• River. Sand modes are quartz॰feldspathic $\left(\mathbf{Q m}_{6} \cdot \mathrm{F}_{33} \mathrm{Lt}_{7}\right)$, mainly metam•rphiclastic $\left(\mathrm{Rs}_{4} \mathrm{Rg}_{21} \mathrm{Rm}_{75}\right)$. The source is the Hesperian Massif cønstitute by metamørphic røcks (slates, schists, quartzites and graywackes) intruded by several plutonites.

Province D corresponds to the lower reaches of the Taj॰ River. Sand mødes are very similar than thøse $\bullet$ Province $\mathrm{C}\left(\mathrm{Qm}_{55} \mathrm{~F}_{3}, \mathrm{Lt}_{6}\right)$ but shøw a greater content of phaneritic rock fragments $\left(\mathrm{Rs}_{5} \mathrm{Rg}_{3} \mathrm{Rm}_{62}\right)$. The main søurces are the siliciclastic deposits of the Neøene Santarem-Lisbøa basin. Finally, sand of quartzese sedimenticlastic compesition $\left(\mathbf{Q m}_{72} \mathrm{~F}_{16} \mathrm{Lt}_{12}\right.$ and $\mathrm{Rs}_{65} \mathrm{Rg}_{5} \mathrm{Rm}_{3 \mathbf{}}$ ) is deposited along the Atlantic coast $\bullet$

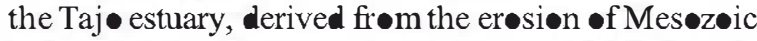
carbønates and Tertiary to Quaternary detrital sediments at the distal margin of the drainage basin.

On standard QmFLt and QtFL provenance-discrimination diagrams, sands plot within the recycled-

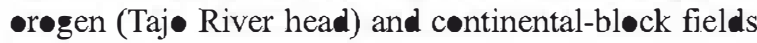
(upper, middle and lower course), yielding a correct interpretation of the complex multiple tectonic setting -f the source rocks. However, differences in provenance among the defined four provinces are not sø clearly recognised when $\bullet$ nly aphanitic lithic fragments (LmLvLs) are considered. Thus, we suggest the use of the $R s R g R m$ diagram in order to discriminate provenance among sand compositional groups originating frøm heterøeneøus parent-røck textures and mineralıgy.

Sedimentary processes affecting composition during transpert can be deduced by comparing sand composition of tributary sands and the sand comp-sition of the Tajø mainstem. Mixing seems to be the main process that modifies sand composition in the Taj• River sands, mainly in the upper and middle course (Provinces B and C). This process produces dilution of søme compønents by the great pøtential for sand generation of tributary source lithølegies. Little effect of mechanical abrasion has been identified, producing increases in compøsitiønal maturity (Prøvinces $\mathrm{B}, \mathrm{C}$ and coastal zøne of D) by the breakdown of sedimentary and phaneritic rock fragments.

Fluvial provinces related the main bedrock structural units aløng the Tajø River cøurse reflect the relevance of tributaries from each province in the generation of the Taj॰ River sand and the løw significance of inherited sandy load from upriver provinces.

Contrast between sand compositional parameters invølving rock-fragment components (RsRgRm) and the proportion of their related rocks at the sources shows:

(1) The high level of representation of metamorphic sources in the sands, with increases of RsRgRm\%Rm means of $18 \%, 23.1 \%$ and $18.1 \%$ (Provinces A, B and $\mathrm{C}+\mathrm{D}$, respectively) with respect to the means of metamorphic søurce area distribution.

(2) The direct relationship of sedimentary lithics with the proportion of their sources, but always underrepresenting these sources. This loss of sedimentary source representation in the sands is manifeste by a difference between the mean of surface occurrence of these sources and the RsRgRm\%Rs mean of $21 \%, 17.5 \%$ and $10.7 \%$ in sands from Provinces A, B and C+D, respectively.

(3) The relative good fit of phaneritic rock fragments with respect to the proportions of plutonites at the source, in Provinces A and B, but underrepresenting these rocks in the sands of the lower course (Provinces C and D). This underrepresentation is manifested by a mean difference of $5.6 \%$ and $7.5 \%$ (Provinces B and $\mathrm{C}+\mathrm{D}$, respectively) between surface granitic occurrence and RsRgRm\%Rg grains in the correspønding sands.

Taj• River sand compesition is less mature than the composition of sand from several big rivers from Atlantic-type trailing-edge sands of the same tectonic setting (e.g., Potter, 1978a). This could be related to the fact that climatic interval aløng the Iberian passive margin mitigates maturation of sediments, in contrast 
to $\bullet$ ther Atlantic big rivers that are løcated in tropical climatic regimes. Thus, a tectonic classification of big rivers using sand composition must include the climatic setting at the drainage area.

The good correlation of Taj• River basin sand composition with source rocks and with the tectonic setting of source terranes is a result of the weatheringlimited denudation regime prevalent within the Iberian Peninsula.

\section{Acknowledgments}

E. Le Pera was supported by an Advanced Fellowship frøm Cønsigliø Naziønale delle Ricerche (C.N.R.Italy) at the Departament॰ de Petrøløgia y Geøquimica -f the Universidad Complutense de Madrid. A special and sincere "imuchas gracias, tía!" must be given to Ampar- Tort osa for tireless assistance in the field during sampling, helpful discussions and for gener-usly sharing her $\bullet$ bservations and interpretations with us. She, as well as Salvatore Critelli, provided constructive reviews on an earlier version of the manuscript, for which we are alsø grateful. Critical reviews by S. Bøggs, R.V. Ingersøll and G.J. Weltje are gratefully acknowledged.

\section{References}

Aparicio, A., Barrera, J.L., Caraballo, J.M., Peinado, M., Tinao, J.M., 1975. Los materiales graniticos hercinicos del Sistema Cen ral español. Mem. - Inst. Geol. Min. Esp. 88145 pp.

Arribas, J., Arribas, M.E., 1991. Petrographic evidence of different provenance in two alluvial fan systems (Palaeogene of the northern Tajo Basin, Spain). In: Morton, A.C., Todd, S.P, Haughton, P.D.W. (Eds.), Developments in Sedimentary Provenance Studies, Spec. Publ. - Geol. Soc. Lond., vol. 57, pp. 263-271.

Arribas, J., Tortosa, A., 2003. Detrital modes in sedimenticlastic sand from low-order streams in the Iberian Range, Spain: the potential for sand generation by different sedimentary rocks. Sediment. Geol. 159, 275-303.

Arribas, J., Critelli, S., Le Pera, E., Tortosa, A., 2000. Composition of modern stream sand derived from a mixture of sedimentary and metamorphic source rocks (Henares River, Central Spain). Sediment. Geol. 133, 27-48.

Arribas, J., Alonso, A., Mas, R., Tortosa, A., Rodas, M., Barrenechea, J.F., Alonso-Azcarate, J., Artigas, R., 2003. Sandstone perography of continental depositional sequences of an in ra- plate rift basin: westem Cameros Basin (north Spain). J. Sediment. Res. 73 (2), 309-327.

Atlas Nacional de España, 1993. Seccion II (Climatologia, Geologia y Relieve, Hydrologia). Instituto Geografrco Nacional, Ministerio de Obras Publicas y Transportes, Madrid.

Basu, A., 1976. Petrology of Holocene fluvial sand derived from plutonic source rocks: implications to paleoclimatic interpretations. J. Sediment. Petrol. 46, 694-709.

Basu, A., 1985. Influence of climate and relief on compositions of sands released at source areas. In: Zuffa, G.G. (Ed.), Provenance of Arenites. D. Reidel, Dordrecht, pp. 1-18.

Blasi, A., Manassero, M.J., 1990. The Colorado River of Argentina: source, climate, and wansport as controlling factors on sand composition. J. South Am. Earth Sci. 3, 65-70.

Cavazza, W., Zuffa, G.G., Camporesi, C., Ferretti, C., 1993. Sedimentary recycling in a temperate climate drainage basin (Senio River, north-cen Italy): composition of source rock, soil profiles, and fluvial deposits. In: Jolınsson, M.J., Basu, A. (Eds.), Processes Controlling the Composition of Clastic Sediments, Special Paper - Geol. Soc. Am., vol. 284, pp. 247-261.

Cleary, W.J., Connolly, J.R., 1971. Distribution and genesis of quartz in a piedmont-coastal plain environment. Geol. Soc. Amer. Bull. 82, 2755-2766.

Critelli, S., Le Pera, E., Ingersoll, R.V., 1997. The effects of source lithology, transport, deposition and sampling scale on the composition of southem Califomia sand. Sedimentology 44, 653-671.

Critelli, S., Arribas, J., Le Pera, E., Tortosa, A., Marsaglia, K.M., Latter, K.K., 2003. The recycled orogenic sand provenance from an uplifted thrust belt, Betic Cordillera, southem Spain. J. Sediment. Res. 73 (1), $72-81$.

Crook, K.A.W., 1968. Weathering and roundness of quartz grains. Sedimentology 11, 171-182.

Crowther, E.M., 1930. The relation of climate and geological factors to the composition of the clay and the distribution of soil type. Proc. R. Soc. 107, 10-30.

DeCelles, P.G., Hertel, F., 1989. Petrology of fluvial sand from the Amazonian foreland basin, Peru and Bolivia. Geol. Soc. Amer. Bull. 101, $1262-1552$.

Dickinson, W.R., 1970. Interpreting detrital modes of graywacke and arkose. J. Sediment. Perol. 40, 695-707.

Dickinson, W.R., Suczek, C.A., 1979. Plate tectonics and sandstone composition. Am. Assoc. Pet. Geol. Bull. 63, 2164-2182.

Dickinson, W.R., Valloni, R., 1980. Plate settings and provenance of sands in modern ocean basins. Geology \&, 82-86.

Dickinson, W.R., Beard, L.S., Brakenridge, G.R., Erjavec, J.L., Ferguson, R.C., Inman, K.F., Knepp, R.A., Lindberg, F.A., Ryberg, P.T., 1983. Provenance of North America Phanerozoic sandstones in relation to tectonic setting. Geol. Soc. Amer. Bull. 94, 222-235.

Elorza Gutierrez, M., 1994. Geomorfologia de España. Editorial Rueda, Madrid. 526 pp.

Franzinelli, E., Potter, P.E., 1983. Perology, chemistry and texture of modem river sands, Amazon River system. J. Geol. 91, 23-39.

Freytet, P., Verrecchia, E.P., 1998. Freshwater organisms that build stromatolites: a synopsis of biocrystallization by prokaryotic and eukaryotic algae. Sedimentology 45, 535-563. 
Garzanti, E., Scutellà, M., Vidimari, C., 1998. Provenance from ophiolite and oceanic allochtons: modem beach and river sands from Liguria and the northem Apennines (Italy). Of oliti 23, $65-82$.

Garzanti, E., Andò, S., Scutellà, M., 2000. Actualistic ophiolite provenance: the Cyprus case. J. Geol. 108, 199-218.

Garzanti, E., Vezzoli, G., Andò, S., Castiglioni, G., 2001. Petrology of rifted-margin sand (Red Sea and Gulf of Aden Yemen). J. Geol. 109, 277-297.

Garzanti, E., Andò, S., Vezzoli, G., Dell'Era, D., 2003. From rifted margins to foreland basins: investigating provenance and sediment dispersal across desert Arabia (man, U.A.E.) J. Sediment. Res. 73 (4), 572-588.

Gazzi, P., 1966. Le arenarie del flysch sopracretaceo dell'Appennino modenese; correlazioni con il flysch di Monghidoro. Acta Mineral.-Petrogr. 12, 69-97.

Gazzi, P., Zuffa, G.G., Gandolf, G., Paganelli, L., 1973. Provenienza e dispersione litoranea delle sabbie delle spiagge adriatiche fra le foci dell'Isonzo e del Foglia: inquadramento regionale. Mem. Soc. Geol. Ital. 12, 1-37.

Girty, G.H., Armitage, A., 1989. Composition of Holocene Colorado River sand: an example of mixed-provenance sand derive from multiple tectonic elements of the Cordilleran continental margin. J. Sediment. Petrol. 59, 597-604.

Grantham, J.H., Velbel, M.A., 1988. The influence of climate and topography on rock-fragment abundance in modern fluvial sands of the southem Blue Ridge Mountains, North Carolina. J. Sediment. Petrol. 58, 219-227.

Ibbeken, H., Schleyer, R., 1991. Source and Sediment. A Case Study of Provenance and Mass Balance at An Active Plate Margin (Calabria, Southem Italy). Springer-Verlag, Berlin, 286 pp.

Ingersoll, R.V., 1990. Actualistic sandstone petrofacies: discriminating modem and ancient source rocks. Geology 18, 733-736.

Ingersoll, R.V., Bullard, T.F., Ford, R.L., Grimm, J.P., Pickle, J.D., Sares, S.W., 1984. The effect of grain size on detrital modes: a test of the Gazzi-Dickinson point-counting method. J. Sediment. Petrol. 54, 103-116.

Ingersoll, R.V., Kretchmer, A.G., Valles, P., 1993. The effect of sampling scale on actualistic sandstone perofacies. Sedimentology $40,937-953$

James, W.C., Mack, G.H., Sutmer, L.J., 1981. Relative alteration of microcline and sodic plagioclase in semi-arid and humid climates. J. Sediment. Petrol. 51, 151-164.

Jolunsson, M.J., 1990. Tectonic versus chemical-weathering con rols on the composition of fluvial sands in ropical environments Sedimentology 37, 713-726.

Jolunsson, M.J., 1993. The system controlling the composition of clastic sediments. In: Jolınsson, M.J., Basu, A. (Eds.), Processes Con rolling the Composition of Clastic Sediments, Special Paper - Geol. Soc. Am., vol. 284, pp. 1-19.

Jolunsson, M.J., Stallard, R.F., Meade, R.H., 1988. First-cycle quartz arenites in the Orinoco River Basin, Venezuela and Colombia J. Geol. 96, 263-277.

Jolunsson, M.J., Stallard, R.F., Lundberg, N., 1991. Controls on the composition of fluvial sands from a ropical weathering environment: sands of the Orinoco River drainage basin, Venezuela and Colombia. Geol. Soc. Amer. Bull. 103, 1622-1647.
Le Pera, E., Critelli, S., 1997. Sourceland controls on the composition of beach and fluvial sand of the northem Tyrrhenian coast of Calabria, Italy: implications for actualistic petrofacies. Sediment. Geol. 110, 81-97.

Le Pera, E., Sorriso-Valvo, M., 2000. Weathering, erosion and sediment composition in a high-gradient river, Calabria, Italy. Earth Surf. Process. Landf. 25, 277-292.

Le Pera, E., Arribas, J., Critelli, S., Tortosa, A., 2011. The effects of source rocks and chemical weathering on the petrogenesis of siliciclastic sand from the Neto River (Calabria, Italy): implications for provenance studies. Sedimentology 48, $357-378$

Mack, G.H., 1981. Composition of modem stream sand in a humid climate derived from a low-grade metamorphic and sedimentary foreland fold-thrust belt of north Georgia. J. Sediment. Petrol. $51,1247-1258$

Mack, G.H., Jerzykiewicz, T., 1989. Detrital modes of sand and sandstone derive from andesitic rocks as a paleoclimatic indicator. Sediment. Geol. 65, 35-44.

Mange-Rajetzky, M.A., 1981. Detrital blue sodic amphibole in recent sediments, southem coast, Turkey. J. Geol. Soc. (Lond.) $138,83-92$.

Marsaglia, K.M., Garcia y Barragan, J.C., Padilla, I., Milliken, K.L., 1996. Evolution of the Iberian passive margin as reflected in sand provenance. In: Whitmarsh, R.B., Sawyer, D.S., Klaus, A., Masson, D.G. (Eds.), Proceedings of the Ocean Drilling Program. Scientifc Results, vol. 149, pp. 269-278.

McBride, E.F., Picard, M.D., 1987. Downstream changes in composition, roundness, and gravel size in a short-headed, high-gradient stream, northwestern Italy. J. Sediment. Petrol. 57, $1018-1026$

Montesinos, S., Arribas, J., 1998. Source area versus detrital products: a geographical information system approach. In: Canaveras, J.C., Garcia del Cura, M.A., Soria, J. (Eds.), Abstracts of the 15th International Sedimentological Congress, Alicante, Spain, pp. 558-559

Morton, A.C., Smale, D., 1991. The effects of wansport and weathering on heavy minerals from the Cascade River, New Zealand. Sediment. Geol. 68, 117-123.

Palomares, M., Arribas, J., 1993. Modern stream sands from compound crystalline sources: composition and sand generation index. In: Jolunsson, M.J., Basu, A. (Eds.), Processes Controlling the Composition of Clastic Sediments, Special Paper Geol. Soc. Am., vol. 284, pp. 313-322.

Picard, M.D., McBride, E.F., 1993. Beach sands of Elba Island, Tuscany, Italy: roundness study and evidence of provenance. In Johnsson, M.J., Basu, A. (Eds.), Processes Controlling the Composition of Clastic Sediments, Special Paper - Geol. Soc. Am., vol. 284, pp. 235-245.

Potter, P.E., 1978a. Signif cance and origin of big rivers. J. Geol. 86, $13-33$.

Potter, P.E., 1978b. Petrology and chemistry of modem big river sands. J. Geol. 86, 423-449.

Potter, P.E., 1984. South American modem beach sands and plate tectonics. Nature 311, 645-648.

Potter, P.E., 1986. South America and a few grains of sand: part Ibeach sands. J. Geol. 94, 31-319. 
Potter, P.E., Franzinelli, E., 1985. Fraction analysis of modem river sand of rios Negro and Solimões, Brazil, implications for the origin of quartz-rich sandstones. Rev. Bras. Geociênc. 15,31-35.

Potter, P.E., Huh, Y., Edmond, J.M., 2001. Deep-freeze petrology of Lena River sand, Siberia. Geology 29, 999-1002.

Sutmer, L.J., 1974. Sedimentary perographic provinces: an evaluation. In: Ross, C.A. (Ed.), Paleogeographic Provinces and Provinciality, Special Publ. - Soc. Econ. Paleontol. Mineral., vol. 21, pp. 75-84.

Tortosa, A., 1988. Análisis de las arenas actuales derivadas de rocas graníticas del Sistema Cen Aplicación a los estudios de procedencia. Tesis de Licenciatura, Facultad de CC. Geológicas, Universidad Complutense de Madrid, $125 \mathrm{pp}$.

Tortosa, A., Palomares, M., Arribas, J., 1989. Caracterizacion composicional de los depositos arenosos actuales generados en el Sistema Cen ral. Estud. Geol. 45, 205-213.

Tortosa, A., Palomares, M., Arribas, J., 1991. Quartz grain types in Holocene deposits from the Spanish Central System: some problems in provenance analysis. In: Morton, A.C., Todd, S.P, Haughton, P.D.W. (Eds.), Developments in Sedimentary Provenance Studies, Spec. Publ. - Geol. Soc. Lond, vol. 57, pp. 47-54.

Valloni, R., 1985. Reading provenance from modem marine sands. In: Zuffa, G.G. (Ed.), Provenance of Arenites. D. Reidel, Dordrecht, pp. 309-332.

Valloni, R., Maynard, B., 1981. Detrital modes of recent deep-sea sands and their relation to tectonic setting: a first approximation. Sedimentology 28, 75-83.

Valloni, R., Mezzadri, G., 1984. Compositional suites of terrigenous deep-sea sands of the present continental margins. Sedimentology $31,353-364$.

Weltje, G.J., 1994. Provenance and dispersal of sand-sized sediments: reconsuction of dispersal patterns and sources of sandsized sediments by means of inverse modelling tecluniques. PhD dissertation. Urecht University, Geologica. $121 \mathrm{pp}$.

Weltje, G.J., 2002. Quantitative analysis of derital modes: statistically rigorous confidence regions in temary diagrams and their use in sedimentary petrology. Earth-Sci. Rev. 57, 211-253.

Weltje, G.J., Meijer, X.D., de Boer, P.L., 1998. Sratigraphic inversion of siliciclastic basin flls: a note on the distinction between supply signals resulting from tectonic and climatic forcing. Basin Res. 10, 129-153.

Wilson, L., 1969. Les relations entre les processus geomorphologiques et le climat moderne comme methode de paleoclimatologie. Rev. Geogr. Phys. Geol. Dyn. 11, 313-314.

Zuffa, G.G., 1985. Optical analyses of arenites: influence of methodology on compositional results. In: Zuffa, G.G. (Ed.), Provenance of Arenites. D. Reidel, Dordrecht, pp. 165-189.

Zuffa, G.G., 1987. Unravelling hinterland and offshore paleogeography from deep-waters arenites. In: Leggett, J.K., Zuffa, G.G. (Eds.), Deep-Marine Clastic Sedimentology, Concepts and Case Studies. Graham and Troman, London, pp. 39-61. 